Artur Nowaczewski

Uniwersytet Gdański

e-mail: artur.nowaczewski@ug.edu.pl

ORCID: 0000-0001-6061-4790

\title{
OBRAZ BAŁKANÓW W TWÓRCZOŚCI ANDRZEJA STASIUKA I MALGORZATY REJMER
}

Polska nie leży tam, gdzie dotąd leżała - to stwierdzenie, od którego rozpoczyna swoje rozważania Przemysław Czapliński w Poruszonej mapie - książce poświęconej wyobraźni geograficzno-kulturowej polskiej literatury z przełomu XX i XXI wieku. Odwołując się do pojęcia geografii wyobrażonej, dziedzictwa myśli Edwarda W. Saida, badacz naszkicował tam wysnuta $z$ polskich narracji mape performatywna ilustrująca, jak wyglądają współczesne samookreślenia polskich pisarzy wobec Wschodu, Zachodu, Południa i Północy. Konfrontowanie siebie $z$ tym, co inne, $z$ kulturami sassiedzkimi, potraktował jako droge do zrozumienia kultury własnej:

Narracje o obcych kulturach, ułożone samodzielnie i zasłyszane, utrwalone na filmie bądź zdjęciach, zaczerpnięte $z$ reportaży społecznych i relacji podróżniczych, $z$ wiadomości telewizyjnych i plotek towarzyskich stanowia doniosły kontekst postrzegania i przekształcania przestrzeni rodzimej. $Z$ podróży do obcych krajów przywozimy nie tyle pamiątki i zdjęcia, ile wyobrażenia, zazdrości, tęsknoty, pomysły i przykłady zmian. Przyglądamy się innym, aby zrozumieć samych siebie. Opowiadamy o innych, aby wypracować narrację o sobie [Czapliński 2017, 10-11].

Pisząc o Południu, P. Czapliński skupił się na zanikaniu Europy Środkowej, na tworzonych przez autorów polskich tekstach przedstawiających obrazy współczesnych Czech i Węgier, gdyż to te kraje wraz z Polską stanowiły część „Zachodu porwanego” w koncepcji Milana Kundery. Nieco na drugim planie znalazła się Europa Południowo-Wschodnia (autor Poruszonej mapy unika niosacego negatywne konotacje określenia Bałkany). Właśnie literacko-reporterskim podróżom polskich pisarzy w tę część Europy u progu XXI wieku warto się przyjrzeć, by spróbować odpowiedzieć na pytanie, co Polakom mogły dać te wyjazdy, czy towarzyszył im określony cel, wreszcie: co wynikało $z$ tych kulturowych spotkań.

Wybór prozy Andrzeja Stasiuka i Małgorzaty Rejmer jako przedmiotu analizy wynika $z$ tego, że pozycje zwiazane $z$ Europa Południowo-Wschodnia / Bałkanami stanowia istotna część ich dorobku, a w wypadku M. Rejmer nawet część główną. Oczywiście wielu innych autorów pisało 
o krajach tego regionu, ale w wypadku tych dwojga pisarzy spotykamy się tyleż $z$ opisem napotykanej rzeczywistości, co $z$ jej artystyczna wizja, rodzajem przyswojenia, wpisania na stałe we własne pisarskie uniwersum, majace wymiar nie tyle obiektywnej czy powtarzalnej mapy - ile mapy osobistej.

Historię terminu Bałkany oraz ich stygmatyzujacych obrazów tworzonych przez podróżników, pisarzy z Europy Zachodniej, znajdziemy w klasycznych już pozycjach: Marii Todorovej Bałkany wyobrażone oraz Dzikiej Europie Božidara Jezernika, do których odwołuja się badacze rozpatrujacy dzieła literatury $z$ tego regionu oraz zachodnich jego przedstawień z perspektywy postkolonialnej [Jezernik 2007; Todorova 2008]. Bałkany od wieków były bliskie Europie w sensie geograficznym, natomiast autorzy wywodzacy się $z$ Europy Zachodniej podkreślali ich odrębność kulturowa, najczęściej stawiając ją niżej od kultur rodzimych. Miała ona swoje źródło w kilkusetletnim panowaniu tureckim na tym obszarze, które pozostawiło ślady wyrażające się przez obecność dużych społeczności muzułmańskich, elementy orientalne w pejzażu architektonicznym oraz późnym akcesie narodów zamieszkujących ten region do kręgu kulturowego nowożytnej Europy. Tak wyraził to B. Jezernik:

Można postawić tezę, że Europa nie istnieje bez Bałkanów. Europejczycy przez wieki odróżniali członków "społeczeństw cywilizowanych" od "prymitywów", "barbarzyńców" i "dzikusów» tylko po to, aby móc uznać siebie za ucywilizowanych. Po to właśnie potrzebowali swojego przeciwieństwa, Innego [Jezernik 2007, 20].

Te sygnowane określeniami bałkanizacja, bałkański kocioł, bałkańska beczka prochu wyobrażenia odżyły w kontekście wojen towarzyszących rozpadowi Jugosławii. Bezkrwawe przejęcie władzy przez siły demokratyczne w krajach zaliczanych przez Kunderę do Europy Środkowej w 1989 roku stworzyło poczucie kulturowego dystansu tamtejszych twórców do południowych sąsiadów, rodzaj protekcjonalnej wyższości nad „chorymi ludźmi Europy”. Polska, Czechosłowacja, Węgry przeszły bowiem bezkrwawo nie tylko transformacje ustrojowa, ale także (w wypadku Czechosłowacji) rozpad państwa na dwa niezależne organizmy państwowe. Inaczej działo się w Rumunii (egzekucja Ceaușescu) oraz w Jugosławii, w której doszło do krwawych konfliktów etnicznych i aktów ludobójstwa. Mieszkaniec Bałkanów stawał się więc „innym”, przeciwieństwem nowoczesnego Europejczyka - rozwiazywał konflikty polityczne za pomoca militarnej przemocy, utożsamiał brutalną męską siłę, nielicząca się $z$ prawami kobiet i cywilów, ulegał nastrojom nacjonalistycznym. Stwarzał zatem $z$ perspektywy zachodniej i także krajów aspirujacych do UE nie tylko problemy geopolityczne, ale i kulturowe, przeczył popularnej w tamtych czasach tezie o końcu historii.

Od końca lat dziewięćdziesiątych XX wieku ten wizerunek powoli zaczynał się zmieniać. Złożyło się na to szereg przyczyn. Sama nazwa Bałkany 
jako metafora kolonizująca zbiorową wyobraźnię mieszkańców Europy Zachodniej jest w debatach akademickich stopniowo zastępowana terminem Europa Południowo-Wschodnia - opisowym, politycznie poprawnym i nie obciążonym negatywnymi konotacjami

- pisała w 2009 roku Magdalena Koch - „Podobnie dzieje się w debatach politycznych, zwłaszcza od kiedy kilka państw regionu weszło do Unii Europejskiej, a kilka kolejnych krajów Półwyspu Bałkańskiego oczekuje w kolejce na akces" [Koch 2009, 92]. Mieszkańcy niektórych państw, które wyłoniły się $z$ dawnej Jugosławii, $z$ powodów historycznych nie uważali ich za część Bałkanów, ale identyfikowali się $z$ kulturą Zachodu ${ }^{1}$ - co znalazło swój finał w przyjęciu ich w poczet państw członkowskich UE (Słowenia - 2004, Chorwacja - 2013). Podobnie prozachodni kurs przyjęły Bułgaria i Rumunia, które są członkami UE od 2007 roku. $Z$ perspektywy identyfikujących się $z$ wartościami demokratycznymi obywateli państw zaliczanych w czasach „żelaznej kurtyny” przez Kunderę do „Zachodu porwanego” również zaczęła się zacierać ich domniemana przewaga nad krajami Południa. Od chwili dojścia do władzy partii prawicowych na Węgrzech (2010) i w Polsce (2015) rządy węgierski i polski zaczęły podkreślać i waloryzować różnice dzielące te kraje od Zachodu, co znalazło $\mathrm{m}$.in. wyraz $\mathrm{w}$ sprzeciwie wobec przyjmowania $\mathrm{w}$ swoje granice imigrantów spoza Europy. Książka Przemysława Czaplińskiego powstała właśnie pod wrażeniem tych wydarzeń i badacz próbował uchwycić zachodzace zmiany ze świadomością, że ma się do czynienia z czymś więcej niż tylko chwilowa polityczna koniunktura.

Nie dysponujemy aktualnie monografiami dotyczacymi najnowszych literackich obrazów Bałkanów w literaturze polskiej, które uwzględniałyby te najnowsze przesunięcia na wyobrażonej mapie Europy, jakkolwiek już w poprzedniej dekadzie pojawiły się pozycje, które podsumowały doświadczenia przed 2013 rokiem. Data ta nie jest żadna cezura, ale to właśnie wtedy ukazały się ksiażki Marty Chaszczewicz-Rydel oraz Macieja Dudy [Chaszczewicz-Rydel 2013; Duda 2013]. Pierwsza z tych monografii dotyczyła obrazu Bałkanów ujawniającego się w reportażach i prozie pisanej przez Polaków, druga opowiadała o recepcji literatur krajów dawnej Jugosławii w Polsce. Prace te różnią się znacząco metodologicznie, przez co pozwalają spojrzeć na problem nie tylko $z$ jednej obiektywizującej, ideologicznej perspektywy, co zawsze może prowadzić do pewnych uproszczeń.

Zdecydowana większość fragmentów prozy A. Stasiuka poświęconych Bałkanom ukazała się w okresie poprzedzającym te podsumowania i jako taka (a także znaczaca, w pewnym stopniu nadająca ton polskiemu odbiorowi krajów bałkańskich) była poddana krytyce, natomiast M. Rejmer swoje książki poświęcone Rumunii i Albanii opublikowała później, au-

${ }^{1} \mathrm{O}$ „ucieczce” Chorwacji z Bałkanów pisał m.in. Bogusław Zielinnski [Zieliński 2008, 44-46]. 
torka mogła więc (choć nie musiała) próbować uniknać zarzutów, z którymi spotykał się A. Stasiuk, a także konstruować swój obraz w pewnej kontrze do starszego kolegi po piórze.

Ze względu na to, że mowa o tekstach literackich będacych zapisem podróży lub zaliczanych do gatunku reportażu, nie bez wpływu na ogląd pisarstwa A. Stasiuka i M. Rejmer musi pozostawać dyskusja wokół oceny i polskiej recepcji twórczości Ryszarda Kapuścińskiego, która została w dużej mierze wywołana publikacją głośnej biografii Kapuściński non fiction. [Zajas 2011, 37-76; Adamczewska 2017, 77-93]. Dotyczyła ona przede wszystkim granic tego, co wolno autorom literatury faktu, ale siła rzeczy ze względu na podróżniczy wymiar twórczości R. Kapuścińskiego rozciagnęła się także na to, na ile obraz odwiedzanych krajów przekazywany rodakom podlega, może podlegać kreacji. Jest to też kwestia, która - jak postaramy się wykazać - zupełnie inaczej jest rozstrzygana przez M. Rejmer i A. Stasiuka. Nie bez znaczenia jest także fakt, że krytyczny ogląd Imperium R. Kapuścińskiego jest punktem wyjścia rozważań P. Czaplińskiego w Poruszonej mapie. Autor Polski do wymiany w sposób bardziej szczegółowy przyjrzał się obrazom Rosji zawartym w wybranych polskich reportażach po 1989 roku i stworzone podczas tej podróży figury będą dla nas użyteczne także przy przyjrzeniu się literackim obrazom $z$ Europy Południowo-Wschodniej.

Pierwsza $z$ tych figur jest wizytator - osoba, która wyjeżdżając do obcego kraju, ma ustalony zespół wartościujących poglądów, stara się dopasować to, co widzi za granica do znanego jej z ojczyzny wzorca. Nie zmienia wyjściowych założeń, nie ma świadomości własnych uprzedzeń, wierzy w swój obiektywizm. Postawę wizytatora podczas wyjazdów do Zwiąku Radzieckiego reprezentował zdaniem P. Czaplińskiego R. Kapuściński. ${ }^{2} \mathrm{~W}$ odmienny sposób tworzy pisarz zbieracz. Autorzy, których można przyporządkować do tej grupy, uprawiają dziennikarstwo uczestniczace, starają się o bezpośredni kontakt $z$ mieszkańcami. Zbieracz zwraca szczególną uwagę na język, notując nowe słowa, które dokumentują dynamiczne społeczne przemiany, praktykuje też teorię Ferdynanda de Saussure'a. Wizytator koncentrował się na systemie norm, natomiast dla zbieracza na pierwszy plan wysuwa się żywa, potoczna mowa. Pierwszy wiedzę przywoził $z$ zewnattrz, drugi musiał ja zdobywać na miejscu, aby posłużyć się lokalnym systemem pojęciowym. P. Czapliński jako przykład autora posługującego się metoda zbieracza przedstawił Jacka Hugo-Badera [Czapliński 2017, 79-83]. Trzecią wreszcie zaproponowana przez niego figura jest tropiciel / tekstualista, który broni nierozdzielno-

2 Wydaje się to zaskakujace, biorac pod uwage, jak starannie przygotowywał się R. Kapuściński do pracy nad swoimi książkami jeszcze przed podróżą, gromadząc możliwie obszerna bibliografię. Ale być może $z$ tych licznych lektur wynikały jego wstępne założenia. Nabywszy dużą wiedzę przed wyjazdem, szukał jej potwierdzenia, nie podważenia. Por. [Czapliński 2017, 16-17]. 
ści języka i podmiotowego doświadczenia [Czapliński 2017, 119-126]. Tropicielowi towarzyszy przekonanie o niegotowości kształtu świata, któremu sens zostaje nadany w akcie pisania. Modelowym przedstawicielem takiego podejścia stał się mieszkajaccy około dwudziestu lat w Rosji Mariusz Wilk, posługujący się terminem pochodzacym od rosyjskiego słowa tropa, który w jego ujęciu oznaczał osobista ścieżkę losu, własną drogę pisarska. Tropiciel wyrusza na poszukiwanie prawdy ze świadomościa, że będzie ją odtwarzał i tworzył. Podkreśla zrośnięcie świata $z$ językiem, przejmuje częściowo ten język, czyni go integralną częścią własnej opowieści, dystansując się jednocześnie od Zachodu, od zachodniego dyskursu. Medium umożliwiającym Mariuszowi Wilkowi uniezależnienie się od zachodniego spojrzenia na ten kraj był język polski, który pisarz na swój sposób „zruszczył”. Jednocześnie pisarz sam zamieszkał na rosyjskiej północy, aby przeżyć/przeżywać tamtejszą rzeczywistość. Jego perspektywa zakładała więc stałe zamieszkanie, możliwie głębokie zakorzenienie w kraju, o którym chciał pisać.

Piśmiennictwo polskie poświęcone Bałkanom jest oczywiście mniej liczne niż pozycje poświęcone Rosji, co jest dość oczywiste $z$ powodów geograficznych i historycznych. Na przestrzeni ostatniego trzydziestolecia widać jednak stałe zainteresowanie tą częścia Europy. ${ }^{3}$ Lata dziewięćdziesiąte XX wieku przyniosły przede wszystkim teksty dziennikarzy, reporterów wojennych. Na ich oceny miały wpływ rozpowszechnione w Polsce oceny rozpadu Jugosławii. Bogusław Zieliński, który prześledził polskie reakcje medialne na wojnę w Chorwacji i Bośni, wyróżnił w nich dominujące tendencje zależne od światopoglądu dziennikarzy. ${ }^{4}$ Ukazało się też szereg reportaży wojennych i powojennych. ${ }^{5}$

3 Zainteresowanie to wyraża się też poprzez tłumaczenia dzieł pisarzy z dawnej Jugosławii na język polski. Szczególną rolę odgrywały w tym zakresie Wydawnictwo Czarne oraz Fundacja i Ośrodek Pogranicze. Szczegółowo te kwestie omawia Maciej Duda [Duda 2013, 40-47].

${ }^{4} \mathrm{~W}$ narracji prawicowej Jugosławia jako twór komunistyczny uciskała zamieszkujące ją narody, a nacją uciskająca innych był dominujący w niej naród, to znaczy Serbowie. W takiej optyce rozpad Jugosławii był traktowany jak wyzwolenie dla innych nacji - Słoweńców, Chorwatów, Muzułmanów w Bośni. W narracji lewicowej natomiast Jugosławia była krajem, który dobrze rozwiazywał kwestię współżycia narodów, a do upadku tego państwa doprowadziły różnorodne czynniki - polityczne, ekonomiczne, ale również międzynarodowe. Przy czym, potępiajac zbrodnie popełniane przez wojska serbskie, potępiano także cele wojenne Serbii, bagatelizowano natomiast okrucieństwa drugiej strony. Czyny jednostek, władz przenoszono na cały naród, co uderzało przede wszystkim w Serbów, rzutowało na obraz całego społeczeństwa [Zieliński 2010, 368], [Chaszczewicz-Rydel 2013, 143-149].

$5 \mathrm{Z}$ tych najwyżej były oceniane reportaże Dawida Warszawskiego Obrona poczty sarajewskiej oraz Wojciecha Tochmana Jakbyś kamień jadła. M. Chaszczewicz-Rydel, starajacca się dokonać oceny polskich reportaży z tego okresu opowiadających o realiach konfliktu, stwierdziła, że: „Mimo podejmowanych przez 
Podróże Andrzeja Stasiuka na południe Europy odbywały się później, głównie w I dekadzie XXI wieku. Ich oddźwięk można znaleźć w takich książkach jak Jadąc do Babadag [2004], Fado [2006], Dziennik pisany później [2010] czy Nie ma ekspresów na żółtych drogach [2013]. Wielu czytelników mimo tego, co na temat swojej prozy twierdzi sam pisarz, czyta te książki, jakby zaliczały się do gatunku reportażu. Tymczasem Andrzej Stasiuk zastrzega:

Nie zajmuję się reportażami, których zresztą nie czytam, bo mnie nudzą. W nich jest tak zwana „prawda”, która mnie zupełnie nie interesuje. Kłamstwa sa ciekawsze. Prywatny osobisty stosunek jest ciekawszy. Reportaż chce być obiektywny, dlatego jest bez smaku, bez właściwości. Ludzie to lubią, da się to czytać, ale literatura to nie jest. Świat jest podstawa cudnego zmyślania, fantazjowania, prywatnych rojeń i to mnie pociaga, a nie jakaś „prawda” jeden do jednego. Ja po prostu zmyślam na temat rzeczywistości [Życie 2015, 148].

Także w sporze wokół biografii Ryszarda Kapuścińskiego pisarz zaliczał się do zwolenników hybrydyzacji gatunku [Zajas 2011, 47-50]. Mimo to nadal właśnie jako „prawdę”, literaturę faktu, non-fiction część czytelników odbiera jego ksiażki. Fascynuje ich bowiem materialny wymiar opisywanego przez niego świata. On sam podkreśla kluczowość dla swojego pisarstwa kategorii doświadczenia:

Jestem pisarzem i opowiadam historie. Staram się w nich zachowywać jak najwięcej życia. Nie w banalnym sensie fabuły, ruchu, zmiany, obserwacji społecznych czy psychologicznych, ale w sensie osobistego doświadczenia. Życiem jest dla mnie spotkanie umysłu, zmysłu, wrażliwości, pamięci ze światem. Spotkanie tożsamości z rzeczywistościa. Po prostu doświadczenie. Zawsze chciałem, żeby doświadczenie przenikało moją opowieść. Cud doświadczenia. Piękny i tragiczny cud zarazem, ponieważ drugiej szansy nie będzie. Nie będzie innego świata. (...) Niewykluczone, że właśnie dlatego zostałem pisarzem. Pisanie daje po prostu szansę powrotu, daje złudne przecież, ale jakże odurzające poczucie, że w jakiś sposób panuje się nad czasem. Że można powrócić do obrazów, zapachów, dźwięków i uczuć. Że istnieje możliwość powtórzenia minionego i minione dotyka nas podwójnie, bo nie jest już oczywistą teraźniejszościa, ale czymś, do czego tęsknimy i oto tęsknota się spełnia. To w swoim pisaniu zawsze chciałem robić: oddalać śmierć ludzi, zdarzeń i rzeczy, wiedząc, że nadejdzie. Oddalać śmierć świata. Wsuwać swoje historie niczym przezrocza między to, co było, a to co będzie. Albo jak zestawy soczewek, które jedno przybliżaja, a drugie oddalaja [Stasiuk 2014, 162-163].

Jak podejść do takich deklaracji? Opowiadając się po stronie prawa do kreacji, do bazowania na własnej pamięci, pogłębiania raz zobaczonych, doświadczonych pejzaży i miejsc, ale pogłębienia ich dla siebie,

większość reportażystów starań, by unikać stereotypów etnicznych i zachować proporcje, niejako tylnym drzwiami docieraja do ich wypowiedzi skondensowane bałkańskie obrazy, klisze spinające indywidualne historie, dostarczające gotowe rozwiazania. Jednoznaczne ustalenie kierunku recepcji tych obrazów jest niemożliwe, lecz z przeprowadzonej analizy wynika, że polscy dziennikarze sa mniej krytyczni względem bałkańskich autostereotypów" [Chaszczewicz-Rydel 2013, 169]. 
dla wyrazistości swojej artystycznej wizji, a nie dla jakiejś obiektywnej prawdy. A. Stasiuk zdystansował się wobec krytyki własnej prozy, która mogłaby dotyczyć kryteriów gatunkowych, ocen politycznych, socjologicznych. W ujęciu A. Stasiuka podróż do krajów bałkańskich zawsze będzie przecież tylko zapisem osobistych subiektywnych doświadczeń, do których autor Jadac do Babadag ma pełne prawo. Warto przesunać więc uwagę $\mathrm{w}$ tym wypadku na sprawy typowo warsztatowe. Pokusić się o odpowiedź doświadczeniem na doświadczenie. Ponowna lektura prozy A. Stasiuka przez pryzmat wspomnień własnych wyjazdów do opisywanych przez niego krajów zwróciła moją uwagę na kilka aspektów, które poczatkowo nie rzucały mi się w oczy.

Po pierwsze: ludzi w bałkańskich utworach A. Stasiuka obserwujemy $z$ pewnego oddalenia, to obserwacje dokonujace się bez interakcji $z$ otoczeniem, pisarz $z$ nimi w zasadzie nie rozmawia. Jego informatorami sa ludzie poznani wcześniej albo przy okazji kontaktów zawodowych, ale trudno mówić o spontanicznie zadzierzgniętych znajomościach.

Po drugie: choć A. Stasiuk pisze o świecie zewnętrznym, to jest on jedynie pretekstem do medytacji pejzażu, podróży w głąb własnej pamięci i wyobraźni.

Po trzecie: jak słusznie zauważył Arkadiusz Bagłajewski, A. Stasiuk nigdy nie był pisarzem palimpsestów, skupiał się raczej na naskórkowych, powierzchownych obserwacjach [Bagłajewski 2004, 96]. Zatem nie daży do pogłębiania wiedzy historycznej, rozpoznania kontekstów tego, co widzi. Własnych wyobrażeń nie poddaje często weryfikacji.

Krytycznie przyglądajac się pisarstwu A. Stasiuka, Marta Chaszczewicz-Rydel zwróciła uwagę, że opisywane przez niego pejzaże są często bezludne. $Z$ kolei, gdy pojawiaja bohaterowie, to sa pozbawieni indywidualności, odgrywają rolę statystów. Badaczka sporządziła nawet swoisty katalog takich postaci. Zaliczaja się do nich lokalni rolnicy, kobiety w chustach, mężczyźni na wozach, klienci miejscowych kawiarni i sklepików, wczasowicze, młodzież (poddana globalizacji, naśladująca wyobrażenia o Zachodzie, sycąca się tandeta i popkultura), snujący się bez celu cwaniacy, Cyganie [Chaszczewicz-Rydel 2013, 232-233]. Fascynacja kultura cygańska bierze się u pisarza $z$ faktu, że wciąż ważniejsze są dla niej baśnie, bajki i legendy, które zastępuja historię dystrybuowana przez państwo. Pisarz sugeruje, że jako opowiadacz historii woli patrzeć na świat ich oczami niż oczami historyków. Książki historyczne nie zapładniaja jego wyobraźni:

Na półce stoją obok siebie Historia Ukrainy, Historia Bułgarii, Historia Węgier, stoi mnóstwo pomniejszych historii i historyjek, łącznie $z$ dziejami Słowacji i Rumunii Eliadego, ale nic $z$ tego nie wynika. Czytam to wszystko przed snem i w końcu zasypiam, lecz jeszcze nie przyśnił mi się Jan Hunyady ani Car Ferdynand [Stasiuk 2006, 16].

Historia znana jedynie $z$ ksiażek, która nie wpisuje się jakoś w osobiste doświadczenia autora Jadac do Babadag, nie jest w stanie zamienić 
się w konkret. Postacie $z$ przeszłości dalszej niż XX wiek, ich działania, nie przekładają się na doświadczana rzeczywistość.

Zgoła inaczej dzieje się w wypadku II wojny światowej. A. Stasiuk stykał się $z$ wieloma, wszechobecnymi w okresie jego dorastania, kulturowymi obrazami wojny, o przeżyciach wojennych opowiadali mu też jego bliscy. Dlatego można mówić o tym, że odczuwa je prawie jak część swojej biografii. Zastosowanie znajduje tu wprowadzone do obiegu przez Mariannę Hirsch pojęcie postpamięci, a więc pamięci odziedziczonej, pamięci drugiego pokolenia, które po rodzicach dziedziczy traumę wojennych doświadczeń. Jest ona podtrzymywana przez artefakty - fotografie, pamiątki, a także przez opowieści bezpośrednich świadków, najczęściej członków rodziny [Hirsch 2010, 254-255]. Choć M. Hirsch używała tego terminu w odniesieniu do ofiar Holokaustu, to znajduje on również zastosowanie do doświadczenia innych zbiorowych traum społeczeństw. Jako że część obrazów wojennych, z którymi spotykał się A. Stasiuk, wpisywała się w kulturę masową, trudno mówić, żeby były to wyłącznie obrazy związane $z$ trauma. Pisarz przyznaje się do wyniesionej $z$ dzieciństwa mieszaniny lęku i fascynacji, które wywoływały w nim historie wojenne:

Bośnia to ostatnia europejska wojna, na która mogłem liczyć. Moje dzieciństwo przesiąknięte było wojną. Żylišmy wojna, wspominaliśmy wojnę, podziwialiśmy ja, baliśmy się jej i pragnęliśmy. Gdy byłem już całkiem dorosły, gdy już zaczynałem się starzeć, w snach wciąż nawiedzała mnie hiperrealistyczna groza bombowców wynurzajacych się zza świetlistego horyzontu. (...) Jechać do Bośni to było tak jak cofać się w jakąś fazę prenatalną. Bo to się miało we krwi, przekazane przez rodziców i dziadków, to krążyło w żyłach i brakowało tylko rzeczywistego obrazu w skali jeden do jednego [Stasiuk 2010, 88].

Nie był w takim stosunku do wojny odosobniony. Jego ukraiński rówieśnik i współautor tomu esejów Moja Europa Jurij Andruchowycz pisał, że od dzieciństwa pociagały go ruiny. Zdaniem współtwórcy „fenomenu stanisławowskiego" krajobraz części świata, w której się wychował, był „dostatecznie wyposażony w tego typu obiekty” - pochylone stare domy, podwórza przesiaknięte zapachami grzyba i moczu [Andruchowycz, Stasiuk 2018, 5-7]. I znowu oddajmy głos A. Stasiukowi:

Pewnie dlatego pół roku wcześniej w Nowym Sadzie z podziwem oglądałem resztki dunajskiego mostu zbombardowanego przez NATO. A jednak to możliwe - powtarzałem sobie $w$ duchu. Tak samo $z$ tymi ponurymi ruinami w Belgradzie. Ciotki i babki mówiły prawdę. Można coś zbombardować, zniszczyć i potem widać to nie w telewizji, tylko tak po prostu. W dodatku to leży tak długo, żeby wszyscy sobie obejrzeli. Jak zwłoki wystawione na pokaz [Stasiuk 2010, 89].

Wychodzi więc na to, że w swoich podróżach pisarz szuka potwierdzenia istnienia rzeczywistości, że chce doświadczać świata bez medialnych pośredników. Podróże są też dla niego wyprawą w głąb własnej pamięci, odkrycia w sobie, w swojej psychice nieuświadomionych, nieuświada- 
mianych miejsc. Sposobem poruszenia wyobraźni, środkiem zaspokojenia melancholii.

Melancholijną figurą stają się także dla A. Stasiuka mapy. W Fado pisarz opisał mape Austro-Węgier z 1900 roku, która ze względu na swoją starość jest tak krucha, że nie daje się wykorzystać w podróży. Współczesne mapy samochodowe starzeją się szybko, rozpadają od powiewu wiatru, od deszczy. Zniszczona mapa - twierdzi A. Stasiuk - jest najlepsza metafora podróży [Stasiuk 2006, 38-39]. Na nią nakładają się wspomnienia $z$ własnych wcześniejszych wyjazdów, pamięć o śladach pozostawionych przez pisarzy, literackich, artystycznych przekształceniach realiów i zdarzeniach, które wpisują się w Stasiukowy pejzaż wyobraźni. Mapa pozwala określić A. Stasiukowi jego miejsce na mapie Europy. Konsekwentnie podkreśla brak fascynacji autora Zachodem. Kreśli osobisty obraz Europy - jak sądzi pisarz - możliwie niezależny od uwarunkowań politycznych. Aby mógł określić, skąd się wywodzi, z jakim obszarem naszego kontynentu się identyfikuje, bardzo pomocna okazuje się dla niego właśnie kartografia:

Posługuje się cyrklem jak dawni geografowie, odkrywcy i wodzowie starych kampanii: mierzę nim odległość. Jednak jego zasadnicza, to znaczy geometryczna funkcja nasuwa się sama. Wbijam więc igłę w miejscu, gdzie teraz jestem, i wszystko wskazuje na to, że pozostanę. Drugie ramię ustawiam tam, gdzie się urodziłem i spędziłem większą część życia. To jest w końcu podstawowa wielkość, gdy próbujemy pogodzić własna biografię $z$ przestrzenia. Między moim Wołowcem a Warszawa jest w linii prostej circa trzysta kilometrów. Oczywiście, nie mogę oprzeć się pokusie i wykreślam wokół Wołowca trzystukilometrowy krag, żeby określić swoją środkową Europę. Linia biegnie mniej więcej przez Brześć, Równe, Czerniowce, Cluż-Napoka, Arad, Szeged, Budapeszt, Żylinę, Katowice, Częstochowę i kończy się tam, gdzie zaczyna, czyli w Warszawie. Wewnattrz jest kawałek Białorusi, całkiem sporo Ukrainy, przyzwoite i porównywalne przestrzenie Rumunii i Węgier, prawie cała Słowacja i skrawek Czech. No i jakaś jedna trzecia Ojczyzny. Nie ma Niemiec, nie ma Rosji - co przyjmuję $z$ pewnym zdziwieniem, ale też $z$ dyskretna atawistyczna ulga [Andruchowycz, Stasiuk 2018, 85-86].

Nie ma tam też (poza fragmentem Rumunii) Bałkanów. Kraje dawnej Jugosławii, Bułgaria, Albania znajduja się poza nakreślonym okręgiem, na zewnątrz. Jeśli więc A. Stasiuk się $z$ nimi konfrontuje, to jednak wciąż jest to różnie stopniowana, ale jednak - obcość. Pisarz nie zakorzenia się w tamtejszym pejzażu, ale jest człowiekiem drogi:

Jutro o świcie jedziemy na Bałkany. Spędzimy dwa tygodnie w aucie i przejedziemy osiem albo dziewięć krajów. (...) W mojej jutrzejszej podróży o paszport zapytają mnie dopiero Chorwaci. Tymczasem na wschodzie, na granicy Unii i Ukrainy kierowcy ciężarówek wjeżdżający $z$ tamtej strony stoja $\mathrm{w}$ kolejkach po trzy, cztery dni. (...) Jeżeli coś otwieramy, to jednocześnie coś musimy zamknąć, od czegoś się musimy odgrodzić [Stasiuk 2014, 61-62].

W twórczości autora Jadąc do Babadag równie ważną rolę, jak odwiedzane miejsca, zajmuje po prostu fakt pokonywania przestrzeni. Jeżdżąc 
na Bałkany, A. Stasiuk najczęściej podróżował samochodem. Opisywał je $z$ perspektywy kierowcy lub turysty poruszającego się autobusem. Jeden $z$ tekstów pomieszczonych w Fado nazwał nawet Stowiańskie on the road (w nawiązaniu do tytułu znanej powieści Jacka Kerouaca). Opisy A. Stasiuka często mogłyby stać się oderwanymi kadrami jakiegoś filmu drogi. Przy okazji tekstu o Miodragu Bulatoviciu polski twórca wyznaje, że w młodości Jugosławia w jego umyśle przybierała cechy fantastycznej krainy, której bogata rzeźba terenu i górskie wybrzeża pobudzały wyobraźnię jak Ameryka:

Ameryka jednak była zbyt daleka, zbyt nierzeczywista i do cna wyeksploatowana imaginacyjnie. Co można pomyśleć o Nowym Jorku albo Kalifornii, skoro tych miejsc dotknęły już wszystkie możliwe myśli? Czy można sobie wyobrazić siebie tam, gdzie w snach podróżują wszyscy? Tymczasem do Jugosławii - sądziłem - nie podróżował prawie nikt. Przynajmniej w snach [Stasiuk 2006, 23-24].

Objawia się zatem tu dążenie do pisarskiej oryginalności, która - jak się zdaje autorowi Fado - łatwiej odnaleźć w zapomnianych lub stygmatyzowanych przez Zachód miejscach Europy. Co ciekawe, filmowe skojarzenia nie opuszczaja go i w wieku dojrzałym - wiejskie, kamienne domy w Rumunii porównuje do puebli.

Zanim głównym kierunkiem podróży A. Stasiuka stał się Wschód, najczęściej wyjeżdżał na Południe. Podłoże tych wyjazdów było jednak podobne. Podkreślał pisarz przede wszystkim ich bezcelowość. A. Stasiuk w czasie podróży na Bałkany bywa zarówno Baumanowskim włóczęga, jak i turysta, kolekcjonerem wrażeń. Włóczęga, bo ruch jest dla niego ważniejszy od celu i wie, że mapy zmieniaja się i zmienia się jeszcze wielokrotnie, nim dotrze do kresu swojej wędrówki. Turystą, bo dąży do zachowania swoich wrażeń, konfrontowania się $z$ innością, egzotyką [Bauman 1993, 22-27]. Swego rodzaju wyjątkowość dawała mu wobec zwykłych turystów literatura - pisarz nawet jeśli korzystał z przewodników turystycznych, $z$ przygotowanej dla turystów infrastruktury, to usuwał najczęściej w cień te utylitarne aspekty swoich wyjazdów $z$ pola widzenia, akcentował natomiast impulsy popychające go do wędrówki czerpane $z$ dzieł literackich. W wypadku Bałkanów autorami przywoływanymi przez niego częściej niż epizodycznie będa Emil Cioran, Danilo Kiš, Miodrag Bulatović.

Pomimo tego nie dą̇̇ł w zasadzie do zgłębiania odwiedzanych kultur, pozostawał raczej po stronie naskórkowych obserwacji. A. Stasiuk reprezentuje typ podróżowania, który w ostatecznym rachunku zostaje ukierunkowany na siebie samego, do wewnątrz. Adrian Gleń określa go jako egzystencjalistę „tropiącego konsekwentnie styk bycia i nicości”, który szuka podobieństwa własnych doświadczeń i powstałych na ich bazie wyobrażeń do wizji religijnych [Gleń 2019, 173]. Badacz zdaje się jednak opierać głównie na „wschodnich” książkach Stasiuka, ewentualnie prozie związanej z Beskidem Niskim. 
Krajem, który obdarzył autor Fado największym sentymentem, była Albania. Nieporównywalna do żadnego innego europejskiego kraju, w odbiorze przyjezdnych kraj archaiczny, niedbający o ekologię, zaśmiecony, chaotyczny architektonicznie, najłatwiej poddający się wyobrażeniom orientalnym. Występujące tu kontrasty dobrze współgraja ze stylem A. Stasiuka, który lubi wyraziste przeciwstawienia. Tu jednak pisarz ma również przyjaciół, którzy wprowadzaja go w specyfikę miejscowej kultury i fragmenty poświęcone Albanii maja większe niż w wypadku tekstów poświęconych innym krajom znaczenie poznawcze. A. Stasiuk podchodzi do tego kraju z empatia, co sprawiło, że M. Chaszczewicz-Rydel zarzuca mu nawet „albanocentryzm” [Chaszczewicz-Rydel 2013, 241-244]. Ta odrębność Albanii sprawia, że wydaje się ona wyizolowana nawet $z$ Bałkanów.

P. Czapliński waloryzował pozytywnie podróże A. Stasiuka w kierunku południowym i ich literackie owoce. Jagoda Wierzejska podobnie wskazywała, że elementy mitu Południa stanowiły podstawy mitu Europy Środkowej i wylicza te, które współtworza obraz Bałkanów A. Stasiuka: nostalgiczne powroty do C.K. Monarchii, idea cywilizacji naddunajskiej, kreacja Cyganów na bohaterów kulturowych oraz topos „poezji ruin” [Wierzejska 2012, 76-82]. Środkowoeuropejski pejzaż najpełniej ma objawiać swoja ruinę na Południu, a zwłaszcza w Rumunii i Albanii. Dlatego zdaniem A. Stasiuka Europejczycy powinni jeździć na Bałkany, by doświadczyć podświadomości swojego kontynentu [Wierzejska 2012, 80]. Co prawda autorka nie widziała w ujęciach A. Stasiuka wielkiej oryginalności, wskazując, że każdy z tych elementów pojawiał się u innych autorów, a nawet że były to wątki wyeksploatowane. Uciekając jednak od osi Wschód-Zachód na Południe, A. Stasiuk uważał, że mit Południa jest Europie Środkowej niezbędny do rozpoznania własnej wyjątkowości [Wierzejska 2012, 84-85].

Innej, bardzo krytycznej ocenie poddała je M. Chaszczewicz-Rydel, akcenty krytyczne pojawiały się też w recenzjach jego książek. Przyczyna tkwiła w odmiennej perspektywie, innych założeniach wyjściowych dla własnych refleksji - P. Czapliński szukał przewartościowań dotyczacych konstruktu Europy Środkowej i w tym sensie odnajdywał $\mathrm{w}$ autorze Jadac do Babadag istotnego modyfikatora tej koncepcji, natomiast M. Chaszczewicz-Rydel jako slawistka w centrum stawiała kraje południowosłowiańskie i walkę $z$ niszczacymi bałkańskimi stereotypami, utrwalanymi przez pisarzy podróżników. Jej zdaniem:

Pisarz nie zdołał dotrzeć do esencji „bałkańskości” czy „środkowoeuropejskości”, gdyż w konfrontacji $z$ rzeczywistościa pojęcia te okazały się sztuczne i relatywne. Potkną się o migotliwość i nietrwałość znaczeń, wypełniając „bałkańskość” coraz to innymi synonimami. W swoich utworach stworzył szereg wartościujacych Bałkany metafor, kierując się przede wszystkim powierzchowną obserwacją i obrazami zaczerpniętymi $z$ innych lektur (głównie pisarzy jugosłowiańskich, pisarek $z$ nurtu feministycznego, Wojciecha Tochmana). Obok w jego utworach funkcjonuja, znane głównie $z$ dyskursów medialnych lat dziewięćdziesiatych, obiegowe opinie i sądy (...) Dostosowując po- 
dróże do absolutyzowanych wyobrażeń, Stasiuk opierał się o geografię symboliczną i ramy interpretacyjne oderwane od rzeczywistości kulturowej regionu.

Prawdopodobnie przyczyna powtarzanych $z$ taką uporczywością obrazów jest poprzestawanie na obserwacji nieuczestniczącej, zewnętrznej i powierzchownej, która uniemożliwia poznanie lokalnych punktów widzenia oraz modyfikację przyjętych założeń [Chaszczewicz-Rydel 2013, 261-262].

Jednak takiej modyfikacji można doszukiwać się w Dzienniku pisanym później. A. Stasiuk opisuje sytuację, z która spotkał się w serbskiej telewizji w Nowym Sadzie. Opowiadał tam na antenie, że podróżuje bez specjalnego celu i sensu i że nie czuje się najgorzej między Belgradem a Tirana, chociaż jego wiedza o tych krajach jest „niedoskonała, fragmentaryczna". Już po emisji podszedł do niego wzburzony serbski operator $z$ pretensjami, że pisarz wymienił Serbię i Albanię w jednym zdaniu, „jakby to były kraje w jakiejś mierze podobne, jakby w ogóle miały ze sobą coś wspólnego". A. Stasiuk nie spiera się $z$ adwersarzem. Pisze, że chciał poczuć sie jak arogant, skarcony głupi Amerykanin, ale „mu nie wyszło" [Stasiuk 2010, 95]. Naiwność czy arogancja polskiego twórcy okazały się w tym wypadku pozorne. Czułość na punkcie narodowej historii, stawianie się w pozycji ofiary, kulturowego przedmurza - po to wszystko nie musi A. Stasiuk jechać do Serbii, zna to z własnego - polskiego podwórka. Zrównanie Serbii i Albanii jest swoista ucieczką od nacjonalizmów, narodowej megalomanii, od polityki.

Za podsumowujący wynik bałkańskich podróży A. Stasiuka można uznać inny fragment:

Całe te Bałkany były heretyckie. Jak jakaś sekta. Europejska jedność to tylko gadanina. Na Wschodzie schizma, na Południu herezja. Tylko na Zachodzie europejska ortodoksja. Tak to wygląda. Możecie sobie uważać, że jeżdżę na safari, że uprawiam „orientalizm”. Jeżdżę, ale nikogo nie pouczam. Nie odczuwam żadnej wyższości. Czasami mnie tylko wkurwiaja. Tak samo jak Polacy, Niemcy, jak Francuzi, jak bladzi Holendrzy (...) Ale nigdy nie ciagnęło mnie do Holandii. (...) Nic tam nie czuję. Oglądam kształty. Porównuję ceny w knajpach. Podobają mi się samochody. Lecz, gdy próbuję sobie wyobrazić jakąś historię, jakąś opowieść, która mogłaby się tam zdarzyć, nic nie przychodzi mi do głowy. Ponieważ jestem kundlem, ponieważ jestem $z$ innych stron (...) ponieważ jestem mieszańcem Wschodu i Zachodu. Dlatego wybieram te heretyckie kraje. (...) Jakbym uciekał przed własnym krajem, jednocześnie poszukując jego wersji hard [Stasiuk 2010, 121-122].

Kim jest A. Stasiuk w podróży, jeśli zastosować typologię P. Czaplińskiego (zbieracz, wizytator, tropiciel)? Brak mu nastawienia na kontakt $z$ ludźmi, co cechuje zbieracza. Poza sfera jego pogłębionego zainteresowania znajdują się też języki i kultura odwiedzanych krajów. Nie stawia przed soba zadania, aby jego teksty niosły rozbudowaną warstwę faktograficzna, skupia się na własnym doświadczeniu, ale jego poglądy na świat pozostają właściwie niezmienne. Fascynacja brzmieniem nazw własnych odwiedzanych miejsc, które $z$ chęcia wylicza, służy wypełnianiu treścia osobistych wspomnień i doświadczeń. Nie jest więc też tropicielem. Najbliżej mu do wizytatora. Wizytator to jednak zgoła inny niż 
R. Kapuściński jako autor Imperium. A. Stasiuk nie aspiruje do roli autorytetu, w mniej usystematyzowany sposób uzupełnia lekturową wiedzę o odwiedzanych krajach. Pomimo że zdaje się poddawać podróżom, towarzyszącym im nastrojom, nie zmienia się pod ich wpływem, nie przewartościowuje swoich wyobrażeń, co najwyżej je pogłębia, czyni bardziej sugestywnymi. Jeździ po to, by doświadczać, być może bowiem jedynie $z$ ruchu jest $\mathrm{w}$ stanie wysnuć nowe opowieści rozgrywajace się na styku „bycia i nicości”. Znużenie Bałkanami przychodzi, gdy sam zaczyna odczuwać powtarzalność własnych opisów i figur wyobraźni.

Kiedy Małgorzata Rejmer zaczęła pisać o Bałkanach, miała już za soba udany i doceniony powieściowy debiut. Zaistniała więc najpierw (w wieku zaledwie dwudziestu czterech lat) jako prozaiczka, nie reporterka. Wskazuje to $z$ jednej strony na rosnąca renomę literatury faktu, która może być przedmiotem artystycznych ambicji, $z$ drugiej zaś na to, że już na wstępie autorka Bukaresztu... dysponowała dużymi możliwościami warsztatowymi. Jej książki dotyczące krajów Europy Południowo-Wschodniej sa świadectwem szybkiego dojrzewania warsztatu pisarki, wykrystalizowania się jej celów twórczych, diametralnie różnych od tych, którymi kierował się Andrzej Stasiuk. Małgorzata Rejmer jest autorką dwóch książek poświęconych krajom bałkańskim: Bukareszt. Kurz i krew [2013] oraz Błoto słodsze niż miód: głosy komunistycznej Albanii [2018].

Początek Bukaresztu... utrzymany jest trochę w stylu A. Stasiuka:

Nie bardzo podoba mi się nowe. Wolę stare warstwy, z których składa się Bukareszt, i to rumuńskie nieokiełznanie, które od zawsze zwodzi system. Tamtego lata 2009 roku autobusy raz po raz wywoża mnie na rubieże, bo na przystankach nie ma żadnych informacji ani rozkładów jazdy. Poznaję przedmieścia, gdzie wszystko jest tymczasowe i złachmaniałe. Przysiadam na krawężniku i zastanawiam się, czy jakimś cudem pojmę ten chaos. Tę bezładną strukturę, która wyrzuca mnie na obrzeża. Istnieja przecież reguły gry, których nie znam [Rejmer 2013, 5-6].

„Rumuńskie nieokiełznanie”, tymczasowość i złachmanienie - wyszczególnione w tym fragmencie mogłyby się znaleźć w prozie autora Jadac do Babadag. A. Stasiuk jednak programowo nie opisywał dużych miast, M. Rejmer zaś znajduje się w centrum stolicy Rumunii. Nie potrafi $z$ początku czytać miasta inaczej niż poprzez powierzchowne wrażenia, może uprawiać flaneuryzm, ale dla rozszyfrowania tekstu miasta potrzebuje towarzystwa miejscowych przewodników. W przeciwieństwie do A. Stasiuka podaje konkretna datę swojego przyjazdu. Jej proces poznawczy będzie się układał odtąd zgodnie $z$ chronologia przyrastania nagromadzonej wiedzy. To istotny szczegół - zdradzajacy, że bardziej ja interesuje historia, nie legenda. Jeśli zaś przedmiotem jej zaintereso- 
wania staną się jakieś legendy czy partie narracyjne mogące je przypominać, to ważny będzie ich kontekst, osadzenie w strukturze całości opisywanego świata.

Po kilku powrotach do Bukaresztu pisarka wraca tu, żeby - jak sama pisze - się „zagnieździć”. Ma ze sobą walizkę pełną ubrań, notatek do nauki rumuńskiego, akcesoriów, za pomocą których ma tu sobie organizować „normalność”. Już w tej pierwszej reportażowej książce M. Rejmer wedle typologii P. Czaplińskiego jest kimś zawieszonym między kondycją zbieracza a tropiciela tekstualisty. Pomieszkuje w Bukareszcie, spisuje powiedzonka znajomych, przysłowia, a nawet przekleństwa.

Znaczaca część Bukaresztu... wypełniona jest rozmowami z Rumunami na temat komunistycznej przeszłości, to $z$ ich wypowiedzi pisarka próbuje ułożyć mozaikę, uzupełniając ja zarówno zapisami własnych wędrówek, błądzeń po mieście, jak i informacjami zaczerpniętymi $z$ literatury przedmiotu. Reportaż ten napisany jest tak, że sprawia wrażenie powstającego na miejscu, zapisywanego na goraco, spięty jest jednak partiami narracyjnymi, które pobyty pisarki w Rumunii ukazują z pewnej perspektywy czasowej. Znajdzie się tu trochę zapisów zwyczajnych sytuacji w poruszaniu się po kraju i mieście, których mógłby dostarczyć każdy samodzielnie poruszający się po Rumunii turysta. Uwypuklone są wątki, które szokuja przyjezdnego - wszechobecność dzikich psów, czy takie, które wskazują na różnice w podejściu do niektórych spraw w Polsce i Rumunii w okresie komunizmu - jak antyaborcyjna polityka rumuńskiego dyktatora i jej społeczne skutki.

Centralna postacią Bukaresztu... jest Nicolae Ceaușescu. To wrażenie wzmocnione jest poprzez opisy miasta, w którym jego rządy zostawiły dotkliwe ślady, do rangi metafory urasta monstrualny budynek Domu Ludowego w centrum stolicy. Uczynienie władcy, dyktatora jednym $z$ bohaterów literackiego reportażu, w zestawieniu $z$ wizją systemu widzianego oczyma zwykłych ludzi, budzi skojarzenia rzecz jasna z najważniejszymi pozycjami w dorobku R. Kapuścińskiego - Cesarzem czy Szachinszachem. M. Rejmer jest w jakimś stopniu kontynuatorka jego dzieła - za temat swoich książek wybierała bowiem te kraje bałkańskie, w których w latach komunizmu panował najostrzejszy, najbardziej restrykcyjny reżim - a zatem Rumunię pod rządami Ceaușescu oraz Albanię Envera Hodży. Sa to też kraje nieczytelne dla Polaków językowo i przez to słabiej znane, egzotyczne i hermetyczne. Reportaże M. Rejmer nie stają się jednak studium władzy czy ustroju, chociaż oczywiście komunizm, jego radykalniejsza forma, jest fascynujacym tłem dla polskiego czytelnika, szukajacego obrazu komunizmu - mówiąc językiem Stasiuka - „w wersji hard”.

Najbardziej fascynuje jednak pisarkę gwałtowność zmian i nieobliczalność:

Ryzyko i tymczasowość są wpisane w życie tego miasta. Raz na kilka dekad trzęsienie ziemi czyści przestrzeń ze słabowitych obiektów i ludzi, którzy nie maja szczęścia. Ale pył i kurz i krew dadzą się zmyć, brud da się zdrapać i już można nakładać 
nową warstwę, nową maskę, przebierać się i przywłaszczać, pożyczać tożsamości [Rejmer 2013, 11].

Metamorfozy, przepoczwarzania przestrzeni miejskiej, oszustwa, które serwuje ludziom ich własna pamięć, stosunek Rumunów do przeszłości to tematy pociagające autorkę. Gdzieniegdzie wyławia $z$ realiów miasta elementy orientalne. Gdy M. Rejmer przebywa wśród swoich rumuńskich znajomych, niczym się oni nie różnią od swoich rówieśników z Polski i innych krajów europejskich. Sa tylko lepiej przystosowani do funkcjonowania w rzeczywistości swojego kraju i pozbawieni ekscytacji, która widać w relacjach pomieszkującej w Rumunii Polki. Kiedy pisarka daje tej ekscytacji dojść do głosu, wychodza jej fragmenty, które niektórzy mogliby odczytać jako orientalizujące, gdyż skupia się na chaosie, nieporządku rozrastającego się w nieprzewidywalny sposób miasta.

Gdy jednak M. Rejmer próbuje napisać coś o pięknie Bukaresztu, jest jej trudno - bo jak mówi jeden $z$ jej rozmówców: „Bukareszt jest słodko-gorzki. Nie znajdzie się w nim łatwego piękna”. Podtytuł kurz $i$ krew odsyła zresztą do bolesnych aspektów rzeczywistości, ale tutaj jednak dość spowszedniałych. Zastanawia też obecność w tytułach M. Rejmer błota. Pierwsza część Bukaresztu... nosi tytuł Komunizm. Złoto i błoto. Błoto powraca też w tytule książki o Albanii - Błoto słodsze niż miód. P. Czapliński zauważał, że w polskim piśmiennictwie poświęconym Rosji była ona domena błota, prowizorki i lodu. Błoto reprezentowało w tym wypadku cywilizację niezdolną obronić się przed natura, klęskę w obliczu substancji nieswoistej, odbierajaccej kształty i formy [Czapliński 2017, 74]. W podobnej funkcji błoto występuje u M. Rejmer. Odwołanie się do zmysłu smaku podkreśla sensualność, konieczność doświadczania opisywanej rzeczywistości. Można wręcz powiedzieć, że autorka potrafi „przyrządzić” Bukareszt, który smakuje młodym Polakom. Potwierdzaja to internetowe recenzje blogerów książkowych świadczące nie tyle o głębszym odczytaniu twórczości M. Rejmer, ile o wiedzy i nastawieniu czytelników wobec Rumunii:

\footnotetext{
Rejmer jest poetką reportażu. Pisze jak Stasiuk, ale lepiej. Stasiuka prawie w ogóle nie da się czytać. Ksiaż̇i Stasiuka kupuje się, stawia na półce i szpanuje przed znajomymi, że się ma takiego autora w kolekcji, ale się ich nie czyta. (...) Ta młoda reporterka potrafiła zainteresować mnie krajem, który do tej pory nie kojarzył mi się $z$ niczym. Był niekształtna plamą na mapie Europy, zasiedlonym przez nijakich ludzi o ciemnych oczach i czarnych włosach. Rząd Rumunii powinien dać pani Rejmer jakiś medal albo chociaż dyplom [Hetman 2014].
}

Co ciekawe, nie jest to opinia jakiegoś przypadkowego internauty, ale przyszłego reportażysty Rafała Hetmana. Można ją złożyć częściowo na karb młodego wówczas (w 2014 roku) wieku i miejsca publikacji. Niemniej jest ona świadectwem tego, że pomimo zaistnienia w języku polskim książek E. Saida, M. Todorovej, B. Jezernika wciąż duży, odległy o kilka godzin jazdy samochodem od granic Polski, kraj jest dla młodych 
i wykształconych Polaków „niekształtna plama”, która nie kojarzy się $z$ niczym. Jeszcze jedna symptomatyczna opinia:

Bo Rejmer Bukareszt nie tylko zrozumiała i oswoiła, ale przede wszystkim nazwała to, czego boją się lub wstydzą nazywać Rumuni. Dlatego ten reportaż jest wyjątkowy - bardzo bowiem intymny, a jednocześnie tak bezwzględnie obiektywny i wynurzajaccy z rumuńskiej niepamięci kształty, barwy, zapachy i przede wszystkim nastroje. Miasta tymczasowego, a przecież silnie akcentującego swą obecność. Miasta chaosu, bezdomnych psów, wiecznej przebudowy i historii, o jakich nie chce się opowiadać ani też ich słuchać. Miasta, gdzie spotyka się azjatyckość, paryskie podróbki architektoniczne, szyk i błoto oraz nieposkromiona dzikość [Czechowicz 2013].

Autorem jest Jarosław Czechowicz, wyróżniajacy się krytyk internetowy, który kilka lat potem sam zadebiutował jako powieściopisarz. W świetle powyższego cytatu wystarcza kilka miesięcy pomieszkać w Bukareszcie, żeby nie tylko zrozumieć i „oswoić” stolicę Rumunii, ale wyrazić to, czego nie potrafią albo boją się nazywać Rumuni. Skąd pewność, że nie ma miejscowych pisarzy, którzy zmierzyli się $z$ tym, co zauważyła w Bukareszcie M. Rejmer? Chyba z przeświadczenia, że skoro nie ma tych ksiązek w języku polskim, nie sa tłumaczone, nie ma ich w ogóle. Rumunia dla tego recenzenta również zdaje się pozostawać w nieokreślonym nigdzie. W oczach takich komentatorów Małgorzata Rejmer przyjeżdża do Rumunii i ja podbija. Taki odbiór książi, mimo entuzjastycznej oceny czytelników, nie jest zgodny $z$ oczekiwaniami pisarki. Świadczy o tym jej praktyka twórcza i kierunek rozwoju własnych aspiracji artystycznych [Szukam 2020].

W reporterskiej książce Błoto słodsze niż miód M. Rejmer jeszcze bardziej bowiem niż w rumuńskiej książce oddaje głos rozmówcom. Wydana została ona po pięcioletniej przerwie. M. Rejmer tworzy powoli, dostosowuje się do najwyższych standardów, których oczekuje się od reportażu. Zapytywana o swoje zdanie na temat granic między reportażem a literatura, w kontekście dyskusji wokół oceny pisarstwa R. Kapuścińskiego, mówi:

Być może Kapuściński to faktycznie przede wszystkim literatura piękna. Jednak reportaże będące jedynie kronikarskim opisem wycinka rzeczywistości, które dystansuja się od języka literackiego, nie mają w sobie pierwiastka uniwersalności, szybko się zużywają. Uważam, że każdy dobry reportaż musi mieć jakiś naddatek - formy, języka, kompozycji, rozłożenia akcentów opowieści. Czytam ich wiele i natychmiast widzę różnicę między rzetelnymi opisami danego wycinka rzeczywistości a książkami wielkimi, które mają tę nadbudowę [Szukam 2020].

W gronie patronów jej pisarstwa należy umieścić Swietłanę Aleksijewicz. To właśnie jej książki są złożone $z$ odpowiednio skomponowanych fragmentów rozmów. Podobnie jak białoruska noblistka M. Rejmer wycisza swój osobisty głos, usuwa $z$ widoku swoja postać. Do książki o Albanii podeszła $z$ podobnym zaangażowaniem, jak to czyni w swoich reportażach S. Aleksijewicz, przede wszystkim odbyła dziesiątki, jeśli nie 
setki rozmów z Albańczykami. Wyeksponowanie świadectw bohaterów przy jednoczesnym wycofaniu się osoby autora, reportera na drugi plan, powoduje, że zbliża się do formy reportażu polifonicznego. Zdaniem Bernadetty Darskiej pozwala też uniknąć banalizacji czy hiperbolizacji przeżyć [Darska 2019, 119]. W udzielanych wywiadach M. Rejmer wyraźnie zaznacza różnice między swoją rumuńską a albańską książką:

To było dla mnie najtrudniejsze zadanie - że muszę się usunać jako ja, pisarka. Nie
mogłam sobie pozwolić na taka literacka szarże jak przy „Bukareszcie”, który wziął
się z moich fascynacji i obsesji, i ta subiektywność nadała ton całej książce. Oczywi-
ście, czytałam mnóstwo o rumunskim komunizmie, ale pisanie „Bukaresztu” było dla
mnie przede wszystkim poszukiwaniem środków wyrazu, literackim szkicownikiem.
Nie zastanawiałam się tak bardzo nad warsztatem reporterskim i relacją z bohaterami
jak przy „Błocie”. Poza tym „Bukareszt” był pisany przede wszystkim przy biurku, czę-
ściowo w Polsce, a częściowo w Rumunii, a „Błoto” pisałam w terenie, bo jeździłam po
całej Albanii, a gdy wracałam do domu, to był to mój dom w Tiranie [Pytałam 2018].

O ile w Bukareszcie Rejmer pomieszkiwała, jak moga to robić uczestnicy wymian studenckich czy literaci udajacy się na stypendium, o tyle związek z Albania okazal się całkiem dosłownie poważny. Autorka mieszka od kilku lat w Albanii, jest związana z Albańczykiem, można więc powiedzieć, że nie jest w tym kraju już całkiem obca, nauczyła się biegle mówić po albańsku, co było bardzo istotne, ponieważ rozmowy $\mathrm{w}$ angielskim ograniczały się do powierzchownych, wciąż powtarzających się banałów. Znając albański, pisarka mogła wejść głębiej w świat swoich rozmówców, a więc także w rolę tropiciela tekstualisty. Akcent w Błocie zostaje postawiony nie na relację człowiek-system, ale na wzajemne relacje między zwykłymi obywatelami. Izolacja kraju nie pozwala przerzucić odpowiedzialności za zło na obcych, na zewnątrz. W tym kraju dziewięćdziesiąt procent ludności stanowia Albańczycy, więc ich narodowość w perspektywie opowieści o historii kraju przestaje mieć decydujące znaczenie i nierealne staje się miejsce ich zamkniętego kraju na mapie Europy.

M. Rejmer zwierza się, że starała się wniknąć w całość świata swoich bohaterów, ich codzienność. Nawiązywała także $z$ nimi relacje, które były czymś więcej niż wydobyciem interesujących pisarkę informacji:

Początkowo widziałam w komunizmie tylko cierpienie. Dopiero później zaczęłam sobie zadawać pytanie, jak ludzie przez te czterdzieści lat panowania Hodży żyli, co myśleli, jak bronili się przed lękiem. Przecież zakochiwali się, wychowywali dzieci, jeździli na wakacje, szukali szczęścia w beznadziei. Wtedy okazało się, że to nie jest tylko opowieść o albańskim komunizmie. To opowieść o tym, w jaki sposób zniewolony człowiek radzi sobie $z$ trauma, $z$ brakiem wolności, poczuciem zagrożenia. Co się dzieje $z$ człowiekiem, który jest ofiara polityki, jak systemy polityczne wpływaja na nasze wybory moralne i promuja określone zachowania - czasem solidarność, a czasem podłość i skrajny egoizm [Pytałam 2018].

W tak ekstremalnych warunkach system wydobywał z Albańczyków zarówno to, co najlepsze - bo zmuszał do ryzykowania własnego 
bezpieczeństwa, komfortu, wolności - jak i to, co najgorsze, bo promował donosicielstwo, brak lojalności, zdradę. O wiele łatwiej rządzi się ludźmi, gdy burzy się siatkę jedności i wspólnoty, gdy człowiek pozostaje sam.

Dla zobrazowania problemów, które niosła tamta rzeczywistość, warto przytoczyć historię, która obrazuje osamotnienie i poczucie niesprawiedliwości, doświadczane przez dziecko $z$ rodziny, która naraziła się władzy:

\footnotetext{
Pewnego razu dziewczynka $z$ klasy spisała ode mnie prace domowa, a potem poszła $z$ nią do odpowiedzi. Dostała najwyższą ocenę, dziesiątkę. Później nauczyciel wywołał do tablicy mnie. Poszedłem $z$ tymi samymi odpowiedziami i dostałem cztery, czyli ocenę niedostateczną. Aż odebrało mi oddech.

- Ale dlaczego? - zawołałem. - Przecież Blerta spisała ode mnie odpowiedzi i przed chwila dostała najlepszą ocenę!

Nauczyciel spojrzał na mnie.

- Twoim psim obowiązkiem jest pomagać jej, ilekroć cię o to poprosi. Ciesz się, że taki nikt jak ty do czegokolwiek się nadaje [Rejmer 2018, 70].
}

Dzieci jako ofiary zawsze najmocniej przemawiaja do ludzkiej wrażliwości. Łatwiej się też $z$ nimi identyfikować emocjonalnie, bo pozostaja niewinne wobec okoliczności politycznych, trudno powiedzieć, aby miały jakiś wybór.

Historie bohaterów Małgorzaty Rejmer rozgrywaja się w ascetycznych krajobrazach kraju rządzonego przez Envera Hodżę. Wszystkiego tam jest mało: mało samochodów, mało jedzenia, mało kolorów - dzieci wyławiaja $z$ morza kolorowe śmieci, opakowania wyrzucone przez ludzi z Zachodu, wynoszone przez wodę na albański brzeg. Zdobyte w ten sposób papierki po zagranicznych cukierkach wklejaja do zeszytów. Ale to też świat, gdzie sa dobre i złe dzieci, dobre sa $z$ dobrych rodzin, a złe ze złych - których krewni narazili się reżimowi. Kara spadała na wszystkich krewnych, którzy byli poniżani jak chłopiec $z$ powyższej opowieści. Jej bohaterowi przydarzyła się jedna $z$ najgorszych rzeczy, której może doświadczyć człowiek - jawna i bezczelna niesprawiedliwość, kiedy za pracę o tej samej wartości jest się ocenianym gorzej niż ktoś inny $z$ pozamerytorycznych powodów. Dodajmy: to nie on odpisal pracę, ale od niego odpisano - został więc ze swojego osiagnięcia niejako okradziony i jeszcze poniżony.

W ksiażce Małgorzaty Rejmer przytłaczające jest nie to, że nie rozliczono osób poprzedniego systemu, ale to, że nikomu nic nie można wybaczyć - bo nikt się nie czuje winny, nikt nie prosi o wybaczenie. Jeden $z$ bohaterów grywa w klubie ze starszym panem w szachy. Gdy pewnego dnia rozmowa schodzi na to, co kto robił w przeszłości, starszy pan bez żadnego wstydu ani żalu zdradza, że pracował w służbie bezpieczeństwa. Albania przedstawiona przez M. Rejmer jest okrutna i zredukowana do rysów rzeczywistości, które przypominaja realia prozy Franza Kafki czy sztuk Samuela Becketta. 
Błoto słodsze niż miód potwierdza, jaką wartość dodaje tej książce fakt, że pisarka mieszka obecnie w Albanii. $Z$ perspektywy osoby mieszkającej na stałe w kraju widać więcej niż z punktu widzenia turysty czy wizytatora. Możliwe jest spojrzenie na ludzi nie jako na obcych, statystów, ale $z$ bliska, poprzez pryzmat ich oceny zdarzeń, zobaczenie życia ich oczami, poprzez ich marzenia. Daje to jakąś namiastkę przejścia na druga stronę lustra. Zobaczenia w nim czegoś więcej niż siebie, własnych oczekiwań, wyobrażeń i przekonań o świecie.

\section{Bibliografia}

M. Rejmer, 2018, Błoto słodsze niż miód, Wołowiec.

M. Rejmer, 2013, Bukareszt: kurz i krew, Wołowiec.

A. Stasiuk, 2010, Dziennik pisany później, Wołowiec.

A. Stasiuk, 2006, Fado, Wołowiec.

A. Stasiuk, 2004, Jadac do Babadag, Wołowiec.

A. Stasiuk, 2014, Nie ma ekspresów przy żóttych drogach, Wołowiec.

I. Adamczewska, 2017, Granice kreatywności w reportażu, „Zagadnienia Rodzajów Literackich" t. 60, z. 1(121), s. 77-93.

A. Bagłajewski, 2004, Mapa, podróż, czas, „Kresy” nr 4, s. 95-101.

Z. Bauman, 1993, Ponowoczesne wzory osobowe, „Studia Socjologiczne” nr 2, s. $7-31$.

M. Chaszczewicz-Rydel, 2013, Obrazy Bałkanów: mity, stereotypy, nowa imagologia, Wrocław.

P. Czapliński, 2017, Poruszona mapa: wyobraźnia geograficzno-kulturowa polskiej literatury przełomu XX $i$ XXI wieku, Kraków.

J. Czechowicz, 2013, Rumunia - tak to jest..., http://krytycznymokiem.blogspot.com/2013/09/bukareszt-kurz-i-krew-magorzata-rejmer.html [dostęp: 15.04.2021].

B. Darska, 2019, Między pamięcia a zapomnieniem, „Twórczość” nr 5, s. 118-120.

M. Duda, 2013, Polskie Bałkany: proza postjugosłowiańska w kontekście feministycznyn, genderowym i postkolonialnym. Recepcja polska, Kraków.

A. Gleń, 2019, Stasiuk. Istnienie, Łódź.

R. Hetman, 2014, Bukareszt. Kurz i krew [recenzja], https://czytamrecenzuje. $\mathrm{pl} /$ recenzja/198/bukareszt-kurz-i-krew [dostęp: 15.04.2021].

M. Hirsch, 2010, Żałoba i postpamięć, tłum. K. Bojarska [w:] E. Domańska (red.), Teoria wiedzy o przeszłości na tle współczesnej humanistyki. Antologia, Poznań, s. 247-280.

B. Jezernik, 2007, Dzika Europa. Bałkany w oczach zachodnich podróżników, tłum. P. Oczko, Kraków.

M. Koch, 2009 „My” $i$ „Oni”, „Swój” i Obcy”: Bałkany XX wieku z perspektywy kolonialnej i postkolonialnej, „Porównania” nr 6, s. 75-93.

Pytałam o najprostsze rzeczy. Z Małgorzatą Rejmer rozmawia Agnieszka Sowińska, dwutygodnik.com, 09/2018 (nr 247), https://www.dwutygodnik.com/ artykul/8038-pytalam-o-najprostsze-rzeczy.html [dostęp: 15.04.2021]. 
E.W. Said, 2005, Orientalizm, tłum. M. Wyrwas-Wiśniewska, Poznań.

K. Stępnik, M. Gawryś (red.), 2010, Południowa Słowiańszczyzna $w$ literaturze polskiej XIX $i$ XX wieku, Lublin.

Szukam opowiadaczy. Z Małgorzata Rejmer rozmawia Aleksandra Wojtaszek, „Tygodnik Powszechny” 12.10.2020, https://www.tygodnikpowszechny.pl/ szukam-opowiadaczy-165260 [dostęp: 15.04.2021]

M. Todorova, 2008, Bałkany wyobrażone, tłum. P. Szymor, M. Budzińska, Wołowiec.

J. Wierzejska, 2012, Mit Południa jako kontrapunkt dla opozycji Wschód-Zachód i podstawa mitu Europy Środkowej, „Porównania” t. 11, s. 71-86.

P. Zajas, 2011, Jak świat prawdziwy stał się bajką: o literaturze niefikcjonalnej, Poznań.

B. Zieliński (red.), 2008, Tradycje pogranicza i przestrzenie tradycji. Od komunizmu do postmodernizmu i i postkolonializmu, Poznań.

Życie to jednak strata jest. Andrzej Stasiuk $w$ rozmowach $z$ Dorota Wodecka, 2015, Warszawa-Wołowiec.

\title{
Obraz Batkanów w twórczości Andrzeja Stasiuka i Matgorzaty Rejmer
}

\author{
Streszczenie
}

Historię terminu Bałkany oraz stygmatyzujących obrazów tworzonych przez podróżników, pisarzy z Europy Zachodniej, znajdziemy w klasycznych już pracach Marii Todorovej i Božidara Jezernika. Po 1989 roku obraz krajów Europy Południowo-WschodWschodniej w Polsce kształtował się pod wpływem zachodniego dyskursu, ale miał też cechy odrębne. Do tych należało sytuowanie Bałkanów wobec mitu Europy Środkowej oraz w pewnym stopniu wspólnego doświadczenia komunizmu. Najciekawsze (i najbardziej wpływowe) narracje polskich pisarzy o krajach tej części Europy wiążą się z twórczością Andrzeja Stasiuka i Małgorzaty Rejmer. Wpisuja się też one w dyskusję o granicach reportażu tocząca się w Polsce w XXI wieku po śmierci Ryszarda Kapuścińskiego.

Słowa klucze: Andrzej Stasiuk - Małgorzata Rejmer - Bałkany - Europa Środkowa - polska literatura faktu.

\section{Image of the Balkans in the works by Andrzej Stasiuk and Matgorzata Rejmer}

Summary

The history of the term the Balkans and stigmatising images of the Balkan area, created by travellers and writers from Western Europe, have been described in works by Maria Todorova and Božidar Jezernik, which can already be considered classical. After 1989, the image of the countries of Southeast 
Europe in Poland was shaped under the influence of the Western discourse, but it also had distinguishing features. These included the positioning of the Balkans against of the myth of Central Europe and, to an extent, against the common experience of communism. The most interesting (and influential) narratives of Polish writers about the countries of this part of Europe are related to the literary works by Andrzej Stasiuk and Małgorzata Rejmer. They also fit into the discussion about the boundaries of reportage that took place in Poland in the $21^{\text {st }}$ century after the death of Ryszard Kapuścinski.

Keywords: Andrzej Stasiuk - Małgorzata Rejmer - Balkans - Central Europe - Polish non-fiction.

Adj. Monika Czarnecka 